IRSTI 06.71.07

UDC 332.021

https://doi.org/10.51579/1563-2415.2021-2.06

\title{
INVESTMENT AND THE MEAT HUB: CONSTRAINTS AND THE PRACTICE OF FOREIGN EXPERIENCE
}

\section{G.I. Adbikerimova*, D.A. Kulanova, A.Y. Yesbolova, K.N. Kydyrbayeva, B. Moldabekov \\ JSC M. Auezov South Kazakhstan University, Shymkent, Kazakhstan \\ e-mail: abdikerimova71@mail.ru}

Annotation. Meat and meat products are the most important food products in most countries of the world. The demand for meat products in the world is growing in accordance with the increase in the level of development of countries and the solvency of the population, and the growth of the world's population is also having an impact. Trends in the global meat market are determined by its largest exporters, including both developed and developing countries (the United States, the European Union, Brazil, Argentina, and China). In recent years, the activity of Asian and South American countries as participants in the global meat market has been growing. The world meat market is segmented by types of meat, each market segment is characterized by certain trends and has features, the study of which allows you to predict the direction of market development, the formation of new niches, which is important for Kazakhstan as a large and promising participant in world trade.

The volume and structure of meat production in Kazakhstan, the position of Kazakhstan in the world meat market as an importer and exporter are evaluated, the factors that hinder the growth of Russian production and export of various types of meat are identified, priority areas for increasing the activity and efficiency of Kazakhstan's participation in the world meat trade are identified.

The article analyzes the trends in the development of world production and the world meat market in the context of its main segments: beef, pork, poultry markets; highlights the features of the commodity and geographical structure of the meat market, focuses on the study of world production and world trade in meat, pricing factors for various types of meat, new directions of development of the world meat market.

Key words: meat industry of the agro-industrial complex, livestock, meat, meat products, sausage products, semi-finished products, investments, investment processes.

This study is funded by the Committee of Science of the Ministry of Education and Science of the Republic of Kazakhstan (Grant No. AP09261075 Formation of the model of the regional food hub as a horizontally integrated structure for ensuring food security (on the example of the meat cluster of Turkestan region) for 2021-2023.

Basic provisions. On the basis of the analysis and evaluation, the directions of improving the system in the context of modernization of the economy of Kazakhstan in the context of globalization are formulated; the analysis of the functioning of the market of meat products of animal husbandry, which is complicated due to a sharp reduction in state support for the industry, the discrepancy in prices for meat products of animal husbandry and material elements of the costs of its production, the violation of economic relations between economic entities of the market, the trends of investment processes in the industry is carried out.

Introduction. The main segments of the world meat market: beef market, pork market, poultry market, lamb market. The most significant share of the world production and the world market of meat is occupied by pork, beef and poultry meat. In 2017 , in the structure of 
world production, according to the International Independent Institute for Agricultural Policy and the UN FAO [1], their share in total production was about $70 \%$, and in the structure of world trade - about 75). Beef is most focused on foreign markets, and its share in world production is slightly lower than in world trade. Pork, on the other hand, is used for domestic consumption in the producing countries to a greater extent than other types of meat.

The main reason is the preferences of Muslim countries, which on the one hand are large meat importers, and on the other hand do not consume pork. According to experts, the global beef market is characterized by relative stability of consumption and a slight decline in production in a number of countries. Developed countries are reducing production, and the increase in production in Asia is focused on meeting domestic demand. The level of beef production declined during the crisis and continues to decline to this day. The decline in beef production is typical for the United States and China, but in the European Union, the level of production is almost unchanged, and production increases in Brazil and India.

As you know, India leads the world in the number of cattle, but Hindu religious traditions prohibit the slaughter of livestock, but now the export of live cattle is rapidly developing, which can ensure the country's place as the largest exporter in the world. Currently, the largest beef exporters are Australia, Brazil, Argentina, Uruguay, and Paraguay. Exports from the United States, the European Union, and, as already mentioned, India are growing. The main importer of beef is Russia. Large volumes of imports also fall on the countries of the European Union, South Korea, Vietnam, Mexico, Canada, Egypt, Venezuela, Iran [2]. In general, experts note positive trends in the development of the global beef market.

The global pork market is more limited in terms of the number of participants. At the same time, there is a fairly dynamic growth in pork production, the amount of demand for this product and its exports. The main producers of pork in the world are China, the European Union and the United States. A significant part of the output of these countries is focused on domestic consumption, which is growing in many countries around the world. The world leaders among pork exporters are the United States and the European Union. Poultry meat is currently in demand on the world market. The level of production and export of poultry meat is influenced by both economic and non-economic factors, in particular, the economic crisis in the United States, the spread of avian influenza in China and Russia.

Materials and methods. The paper uses methods of modeling and comparative analysis. To solve individual tasks, the methods of the "tree" of goals and expert assessments were used. The information and empirical base of the research is the normative legal acts of the regional and municipal levels; official data of the republican and regional authorities; methodological, scientific, educational and reference literature, materials of the Internet, as well as research conducted by the authors.

The methodological research is a general method of scientific knowledge-analysis and synthesis, Content-media analysis of sociography, a system-comparative method that allows us to determine the genesis, sequence and functioning of the stages of development of a meat hub within the framework of the pandemic, investment attractiveness and effectiveness of adapting foreign experience in managing a meat hub in Kazakhstan.

Results and discussion. It is now quite clear that the import of international investments is one of the most effective and fastest ways to revive the investment process in the republic. This is due to the lack of funds for the implementation of structural and investment policy in priority areas, such as fuel and energy, metallurgy, oil and oil refining, gold mining, transport and communications, saturation of the domestic market with consumer goods and food. 
Investment policy is the most important element of the country's economic strategy and is determined by its goals and objectives [3]. The state policy of attracting international capital and investment in accordance with the logic of economic reforms proceeds from the need to maximize its assistance to the structural restructuring of production in the conditions of crisis and high inflation, as well as the development of market transformations, and a significant increase in the investment activity of public and private investors.

According to Western experts, the investment climate in Kazakhstan is generally favorable, but serious obstacles in the form of bureaucratic obstacles, financial risks, shortcomings in tax legislation and administration, insufficiently developed legal infrastructure in the field of insurance, collateral, etc. can begin to constrain the process of foreign capital and investment $[4,5]$. On the other hand, Kazakhstan is considered an attractive market for foreign investors based on the most basic parameters of the business climate; the republic is characterized by a large market potential, an abundance of natural and labor resources. The potential profitability of investments is a significant factor for investors who expect to get more profit from investments in Kazakhstan.

All this has to a certain extent contributed to the fact that foreign capital has become the most serious factor in the economy today. Almost all of the insignificant growth achieved in the economy is due to foreign capital, which has occupied a serious and long niche in the economic development of the country [6]. Purchases of goods, construction of large facilities with the funds of international loans, participation of foreign capital in direct form, during the transfer to management and purchase of controlling stakes in enterprises-these and other events have become an integral part of the economic life of the republic [7].

Meanwhile, as the experience of other countries of the world shows, foreign capital can play both a positive (if used correctly) and a negative role, plunging the economy and the country into an acute debt crisis. Attracting it to the maximum size is not an end in itself (unfortunately, this is sometimes poorly understood by government officials), although Kazakhstan attracts hundreds of times less than the countries of Latin America, Eastern Europe, China, and South-East Asia.

The problem is to effectively use and give a positive multiplier effect to investments, which would allow the proportionately increased level of economic development to attract new capital, and then move to self-financing investments.

Animal husbandry, like grain crops, is almost ubiquitous, with pastures covering three times as much land as arable land in the world. Along with crop production, animal husbandry is the second major part of agriculture.

So, this industry is divided into four main types, namely cattle breeding, pig breeding, sheep breeding and poultry farming. In Kazakhstan, cattle breeding is considered a traditional activity [8]. Despite this fact, according to Statista, Kazakhstan is not among the leaders in the number of cattle (cattle). According to the results of 2020, there were 7.4 million heads in Kazakhstan. At the same time, the cumulative annual growth rate over the past 8 years was $3.9 \%$, while the global figure for the same period was only $0.1 \%$.

In recent years, there has been a trend in livestock farms to increase the number of young animals, which is reflected in the growth of labor productivity and profitability of the industry [9]. Thus, in developing countries, more than half of the total number of cattle is owned by private farms and households, which in some cases negatively affects the volume and quality of products produced. This fact is due to the fact that private farms are not always able to provide livestock with the necessary conditions [10].

According to Statista, the global market is experiencing an increase in meat production. In the period from 2017 to 2019 , global meat production increased from 350 million tons 
to 364 million tons, while in 2020 the figure fell to 363 million tons. This trend is also inherent in the Kazakh market. Thus, in the period from 2017 to 2020, Kazakhstan recorded a stable positive trend in meat production. In 2017, Kazakhstan produced 0.96 million tons, and in 2020 the figure reached 1.12 million tons. This fact is associated with the migration of the population to the cities, which in turn leads to an increased consumption of meat.

At the same time, it is worth noting that in 2019, the production of poultry meat on the world market accounted for $38 \%$ of the total volume, pork $36 \%$, beef $21 \%$ and lamb $5 \%$. In Kazakhstan, the market structure is significantly different. At the end of 2020, the top three leaders in meat production included: beef-501.4 thousand tons, or $45 \%$ of the total volume, poultry-223 thousand tons, or $20 \%$, lamb-151.9 thousand tons, or $13 \%$ of the total volume of slaughtered livestock. Thus, in terms of production volumes, beef, poultry and lamb are considered the most popular in Kazakhstan at the moment.

According to the results of 2020, the share of meat on average per capita in the diet of the population was $7.9 \%$. Thus, milk and dairy products occupy $25.2 \%$ (252.6 liters) of the total diet; eggs-19.4\% (193 pcs.); vegetables (including potatoes) - 14\% (139.8 kg); bread products and cereals $-13.6 \%(136.3 \mathrm{~kg})$; meat and meat products $-7.9 \%(78.8 \mathrm{~kg})$. Thus, the share of products produced by all types of animal husbandry in the diet of the population was more than 50\%, which indicates a significant demand in the market.

It is worth noting that at the end of 2020, retail prices of agricultural products increased in all categories. So, the most expensive meat was horse meat with bones, its price was 1,884 tenge per kilogram. The cheapest meat was chicken, but the price of this meat increased the most (15.5\%) and amounted to 875 tenge per kilogram.

After analyzing these markets over the past few years, we can conclude that these markets are promising for investment. Thus, despite the decline in gross crop production in physical volume for 2020 , their gross volume in monetary terms continues to grow, amounting to 2,897 billion tenge. Thus, the increase was $20.1 \%$ compared to 2019 . In animal husbandry, it is worth noting an increase in both the physical volume of production and in monetary terms. At the end of 2020, the volume amounted to 2,306. 4 billion tenge and increased by $12.5 \%$.

Thus, we can conclude that at the moment the meat hub is more profitable in terms of turnover. It is important to note that the Government of Kazakhstan continues to actively develop strategies to support these industries. Today, the gross production of meat in slaughter weight covers $87 \%$ of the domestic market. At the same time, the Government of the Republic of Kazakhstan introduces restrictive measures on the export of breeding stock in order to preserve the domestic product on the domestic market. As for crop production, Kazakhstan is trying to increase the area of irrigated fields. According to the government's plan, by 2028, it is expected to increase such land to 3.5 million hectares, which will significantly increase productivity.

It is obvious that the expansion or re-profiling, as well as the diversification of the business, require serious financial investments. It is important for companies that will be looking for investments to undergo a financial assessment and consultation in order to demonstrate their transparency and reliability as a partner.

Today, our country can confidently choose its own investors from a fairly decent queue of those who want to work in the Kazakh state. During the period of Kazakhstan's independence, $\$ 330$ billion of foreign investment was attracted from more than 120 countries. The main part of investments-more than $50 \%$ is accounted for by the countries of the European Union, the United States of America - $15 \%$ of foreign direct investment, about $5 \%$ are investments from the UK and China. 
It is worth noting that every year the economy of Kazakhstan becomes more competitive and attractive for investors. At the end of October this year, 16.8 thousand companies with foreign capital are operating in the country - $18.1 \%$ more than in the same period a year earlier (14.3 thousand companies). This year, Kazakhstan entered the top 55 countries in the global competitiveness ranking, rising to 4 lines.

At the same time, Kazakhstan plays a key role in the implementation of the Belt and Road initiative. More than 3,000 km out of a total of $10,000 \mathrm{~km}$ will pass through the territory of Kazakhstan, making it an important section of the main land corridor and significantly reducing the time and cost of transportation. Since independence, Kazakhstan has attracted more than $\$ 330$ billion in foreign direct investment.

According to UNCTAD, in 2018, almost $60 \%$ of investments in Central Asian countries are accounted for by Kazakhstan. At the same time, over the past ten years, the national economy has received $\$ 250.2$ billion, or about $80 \%$ of all historically formed investment flows. This fact indicates the effectiveness of the investment policy.

Investors are provided with a full range of support services according to the principle of «one window» - from the search for an idea to the commissioning of the project, as well as monitoring in the post-investment period, which allows you to work with each investor and project point-by-point, at all levels.

This mechanism allows you to broadcast projects from the regions directly to foreign institutions to search for potential investors, and vice versa.

\section{Conclusion}

Today, thanks to the team work of the Government, a «soft infrastructure» has been built for investors: systematic work has been established to explain Kazakhstan's legislation and procedures, transparency of decision-making has been ensured, and the administrative burden has been reduced. It is a well-known fact that it is important for any company not only to have a promising industry, sales markets, but also a comfortable business environment.

And this includes the institutional environment, the stability of the legislation, the conditions of the visa regime and a lot of other components. Therefore, new approaches have been developed and implemented, which include the development of investment proposals, investor support, and the identification and elimination of adverse factors.

The issues of supporting domestic investors include such important issues as finding strategic investors with a willingness to expand the business, entering new markets, and ensuring the synergy of production and sales ties, since investors need local partners and conscientious suppliers.

In order to increase the efficiency of work on attracting investment in the country's economy, an information and monitoring CRM system is being introduced, which includes all agreements, roadmaps for their implementation, and tasks are assigned to all participants in the process - central state and local executive bodies.

In total, the KAZAKH INVEST information and monitoring system currently contains 228 investment projects for the development of the meat hub, worth $\$ 54.3$ billion. Of these, 168 projects worth about $\$ 46$ billion with the participation of foreign investors are being implemented and are being worked out to a high degree.

\section{References}

1. Nelson, Kenneth E. and Lawrence Deuwer. Meat Industry Price Spreads: What Do They Mean? Agricultural Outlook, December 2015, pp. 11-16.

2. MacDonald, James M., Michael E. Ollinger, Kenneth E. Nelson, and Charles R. Handy. Long-Term Developments in Trade in Feeds and Livestock Products. Economic Research Service, USDA. Foreign Agricultural Economic Report 199. 000. 
3. John H. Dyck and Kenneth E. Nelson. Structure of the Global Markets for Meat. Market and Trade Economics Division, Economic Research Service, U. S. Department of Agriculture, Agriculture Information Bulletin No. 785. September 2014.

4. Ignatova T.V., Kijashhenko T.A., Ashirova M.N. Sovershenstvovanie pokazatelej ocenki jeffektivnosti dejatel'nosti mestnyh organov vlasti // Nauchnoe obozrenie. 2014. № 8. S. $416-423$

5. Kuznecov V.V. Prioritety gosudarstvennoj podderzhki sel'skogo hozjajstva Rossii // Nauchnoe obozrenie. Saratov. 2014. № 4

6. C. Beghin, David Roland-Hoist, and Dominique van der Mensbrugghe Global Agricultural Trade and the Doha Round: What Are the Implications for North and South? John Working Paper 02-WP 308 June 2014

7. Food security of the Republic of Kazakhstan: current state, problems and main ways out of the food crisis. [Electronic resource]. https://articlekz.com/article/12127

8. Макроэкономические и социокультурные факторы, определяющие развитие глобального потребительского рынка. Тенденции развития потребительского спроса в России. BBPG Business Forum „Marketing Director". GfK Group. 2006

9. Hill, Charles W. L. International Business: Competing in the global Marketplace. The McGraw-Hill Companies, Inc., NY 10020. 2013, p. 159.

10. The Treaty on the Eurasian economic Union (signed in Astana 29.05.2014) (as amended on 08.05.2015). http://www.consul tant. ru/document/cons_doc_LAW_163855/

\section{References}

1. Nelson, Kenneth E. and Lawrence Deuwer. Meat Industry Price Spreads: What Do They Mean? Agricultural Outlook, December 2015, pp. 11-16.

2. MacDonald, James M., Michael E. Ollinger, Kenneth E. Nelson, and Charles R. Handy. Long-Term Developments in Trade in Feeds and Livestock Products. Economic Research Service, USDA. Foreign Agricultural Economic Report 199. 000.

3. John H. Dyck and Kenneth E. Nelson. Structure of the Global Markets for Meat. Market and Trade Economics Division, Economic Research Service, U. S. Department of Agriculture, Agriculture Information Bulletin No. 785. September 2014.

4. Ignatova T.V., Kijashhenko T.A., Ashirova M.N. Sovershenstvovanie pokazatelej ocenki jeffektivnosti dejatel'nosti mestnyh organov vlasti // Nauchnoe obozrenie. 2014. № 8. S. $416-423$

5. Kuznecov V.V. Prioritety gosudarstvennoj podderzhki sel'skogo hozjajstva Rossii // Nauchnoe obozrenie. Saratov. 2014. № 4

6. C. Beghin, David Roland-Hoist, and Dominique van der Mensbrugghe Global Agricultural Trade and the Doha Round: What Are the Implications for North and South? John Working Paper 02-WP 308 June 2014

7. Food security of the Republic of Kazakhstan: current state, problems and main ways out of the food crisis. [Electronic resource]. https://articlekz.com/article/12127

8. Makroekonomicheskie i sotsiokulturnye faktory, opredelyayushchie razvitie globalnogo potrebitelskogo rynka. Tendentsii razvitiya potrebitelskogo sprosa v Rossii. BBPG Business Forum „Marketing Director". GfK Group. 2006

9. Hill, Charles W. L. International Business: Competing in the global Marketplace. The McGraw-Hill Companies, Inc., NY 10020. 2013, p. 159.

10. The Treaty on the Eurasian economic Union (signed in Astana 29.05.2014) (as amended on 08.05.2015). http://www.consul tant.ru/document/cons_doc_LAW_163855/ 


\title{
ИНВЕСТИЦИИ И МЯСНОЙ ХАБ: СДЕРЖИВАЮЩИЕ ФАКТОРЫ И ПРАКТИКА ЗАРУБЕЖНОГО ОПЫТА
}

\author{
Г.И. Абдикеримова *, Д.А. Куланова, А.Е. Есболова,
}

К.Н. Кыдырбаева, Б. Молдабеков

НАО Южно-Казахстанский университет им. М. Ауезова, Шымкент, Казахстан e-mail: abdikerimova71@mail.ru

Резюме. В статье проводится анализ ключевых проблем сдерживающие развитие мясной отрасли Республики Казахстан. Рассматриваются основные проблемы производства и переработки мясной продукции в Республики Казахстан и определень факторы, влияющие на инвестиционные прочессы в мясной отрасли. Для решения возникших проблем государственными структурами разработаны Программы развития агропромышленного комплекса, которые должны повлиять на эффективные ведения агробизнеса и повышающее конкурентоспособность продукции АПК.

Ключевые слова: мясная отрасль АПК, скот, мясо, мясные продукты, колбасные изделия, полуфабрикаты, инвестиции, инвестиџионные прочуессы.

Данное исследование финансируется Комитетом науки Министерства образования и науки Республики Казахстан (Грант № АР09261075 Формирование модели регионального продуктового хаба как горизонтально интегрированной структуры в цеелях обеспечения продовольственной безопасности (на примере мясного кластера Туркестанской области) на 2021-2023 г2.

\section{ИНВЕСТИЦИЯЛАР ЖӘНЕ ЕТ ХАБЫ: ТЕЖЕУШ ФАКТОРЛАР ЖӘНЕ ШЕТЕЛДІК ТӘЖІРИБЕ ПРАКТИКАСЫ Г.И. Абдикеримова *, Д.А. Куланова, А.Е. Есболова, К.Н. Қыдырбаева, Б. Молдабеков}

КАҚ М. Әуезов атьндавы Оңтүстік Қазақстан университеті, Шымкент, Қазақстан e-mail: abdikerimova71@mail.ru

Түйін. Мақалада Қазақстан Республикасының ет саласының дамуын тежейтін негізгі проблемаларва талдау жасалады. Қазақсттан Республикасында ет өнімдерін өндіру мен қайта өңдеудің негізгі проблемалары қарастырылады және ет саласындагы инвестициялық прочестерге әсер ететін факторлар айқындалды. Туындаван проблемаларды шешу үшін мемлекеттік құрылымдар агробизнесті тиімді жүргізуге ықпал ететін және АӨК өнімдерінің бәсекеге құабілеттілігін арттыратын агроөнеркәсіптік кешенді дамыту бавдарламаларын әзірледі.

Кілт сөздер: АӨК ет саласы, мал, ет, ет өнімдері, шұжық өнімдері, Жартылай фабрикаттар, инвестициялар, инвестицияльққ процестер.

Бұл зерттеуді Қазақстан Республикасы Білім және вылымм министрлігінің Ғылымм комитеті қаржыландырады 2021-2023 жылдарzа арналван грант №AP09261075 Азықтүлік құаіпсіздігін қамтамасыз ету мақсатында көлденен біріктірілген құрылым ретінде өнірлік азық-түлік хабының моделін құлылттастыру» (Түркістан облысының ет кластері мыссалында) 